We thank Mrs G. Csch, Miss A. Fonagy and Mrs Z. Graf for their assistance.

\section{B. Daros}

MAGDA HoRVÁth

Frédéric Joliot-Curie

National Research Institute for Radiobiology

and Radiohygiene,

Budapest.

Received April 4. 1967.

' Lamerton, I. F., Pontifex, A. H., Blackett, N., and Adams, K., Brit. $J$ Radiol., 33, 287 (1960).

${ }^{2}$ Lajtha, L. E., Prog. Biophys. and Phys. Chem. (edit. by Butler, X. A. v., Katz, B., and Zirkle, R. E.), 11, 109 (1961)

Maurice, P. A., and Jeanrenaud, A., Nature, 200, 1221 (1963).

'Dalos, B., Nature, 212, 1252 (1966).

${ }^{5}$ Sober, H. A., and Peterson, E. A., Fed. Proc., 17, 1116 (1958).

Wagner, H., Radiobiol. Radiother., 4, 29 (1963).

' Müller, J., Nature, 178, 43 (1956).

\section{Reduction of the Absorption and Retention of Strontium in Rats}

THE absorption and retention of diotary strontium can bo redueed by supplementing the diet with an equimolar mixture of barium and sodium sulphates ${ }^{1,2}$, calcium phosphates $^{3}$, or sodium alginate ${ }^{4,5}$. The possibility of romedial measures to protect a population exposed to a high concentration of strontium-90 in the diet makes these results particularly interesting. Promising results havo been obtained from each of the dietary supplementations, and the purpose of the present investigation was to eompare the effectiveness of the different troatments in rats of the same strain and age in similar conditions.

Sixty-three female albino rats, 8-9 weeks old and weighing about $130 \mathrm{~g}$, were used. All rats had been fed the standard diet $(1.0 \mathrm{~g}$ calcium, $0.5 \mathrm{~g}$ phosphorus $/ 100 \mathrm{~g}$ diet) with water $a d$ lib. since weaning. They were divided into seven groups of nine animals each and fed for 8 days on the standard diet or diets supplemented with the additives shown in Table 1 . On the sixth day, the rats were placed in separate metabolism eages and given tracer amounts of almost carrier-free strontium-85 and calcium47 in the drinking water for 2 days before they were killed on the eighth day. Urine was collected from each rat during tho last 3 days of the experiment and the gut was removed after death, before drying and ashing the separate carcasses. All assays of radioactivity were made on a single channel gamma scintillation counter ${ }^{6}$.

The results are shown in Table 1 . The amounts of strontium-85 in the carcass and in the urine plus carcass are moasures of the body retention and the absorption of the radioactive marker, respectively. For calcium-47, however, when dietary calcium is increasod by supplementation with calcium and phosphorus, the body retention and absorption of the marker decreases, and the fall in the percentage of calcium-47 in the carcass and in the urine plus carcass which we observed is to be expocted.

Table 2 shows the comparative absorption and retention of strontium relative to that in the control animals (no supplementation). It should be noted that the

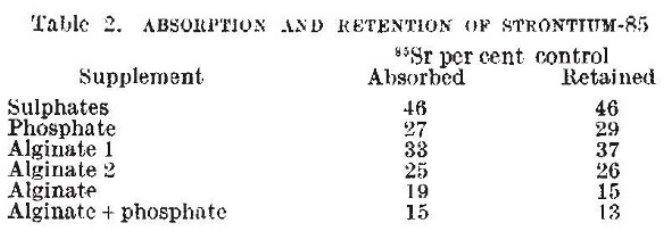

sulphate and phosphate supplementations wero equimolar (60 mmoles/l.).

The decreased retention and absorption of strontium-85 shown in 'Table 2 were achieved with only about 30 per cent change in the absorption and retention of calcium. The combined therapy with alginate and calcium phosphate supplementation gave the greatest roduction in the strontium absorbed or rotained that we have obtained so far from any dietary supplementation.

'This work was supported by the Federal and Ropublic Councils for Sciontific Researeh, Belgrade and Zagrob.

Krista Kostiat Tea Malukovió

M. KaDIĆ

R. MANiTAŏ́EIĆ́

Institute for Modical Research,

Zagreb, Yugoslavia.

\section{G. E. Harrison}

MRC Radiobiological Research Unit,

Harwell, Berkshire.

Received March 1;, 1967.

1 Volf, Y., and Roth, Z., Acta Radiol., 3, 216 (1965)

"Volf, Y., and Roth, Z., Acta Radiol., 4, $481(1966)$.

Harrison, G. F., Howells, G. R., Pollard, J., Kostial, K., and Manitaševic, 1R., Brit. J. N'utrit., 21, 581 (1966).

Waldron-Edward, D., Paul, J. M., and Skoryna, S. C., Nature, 205, 1117 (1965).

5 Harrison, f. F., Humphreys, E. R., and Sutton, A., Science, 152, 655 (1966).

Kostial, K., Lutkið, A., Gruden, N., Vojvodix, S., and Harrison, G. E., stial, K., Lutkic, A., Gruden, N., Vo
Intern. .I. Rndiat. Biol., 6, 341 (1963).

\section{PATHOLOGY}

\section{Adverse Effects on Offspring of Tranquillizing Drugs during Pregnancy}

I $\mathrm{T}$ has recently been shown that the injection of certain tranquillizing drugs during pregnancy produces loss of weight and defects of maze learning depending on the stage of pregnancy in which the injections are given ${ }^{1}$. The same workers obtained inconclusive evidence of the effect of tranquillizers on conditionod avoidance training. The present study investigates further the possible effect on conditioning of such treatment and attempts to verify the effects on weight.

Twolve groups of female rats were used in a $4 \times 3$ factorial design. One independent variable, the drug administered, involved four groups-experimental subjects the mothers of which wore given reserpine (Res), meprobamate (Mep), chlorpromazine (Chl), or distilled

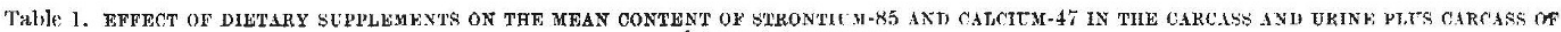

\begin{tabular}{|c|c|c|c|c|c|c|c|}
\hline \multirow[b]{2}{*}{ Group } & \multirow{2}{*}{\multicolumn{2}{|c|}{$\underset{(\mathrm{g} / 100 \mathrm{~g} \text { diet })}{\stackrel{\text { Total }}{\text { dietary }} \mathrm{P}}$}} & \multirow{2}{*}{$\begin{array}{c}\text { Additive/ } \\
100 \mathrm{~g} \\
\text { diet }\end{array}$} & \multicolumn{4}{|c|}{ Percentage of oral dose } \\
\hline & & & & \multirow{2}{*}{$\begin{array}{l}\text { Carcass } \\
11 \cdot \%(0 \cdot \overline{6}) \ddagger\end{array}$} & \multicolumn{3}{|c|}{ Percentage of oral dose Urine + carraks } \\
\hline Control & $1 \cdot 0$ & 0.5 & - & & $35.4(2 \cdot 5)$ & $15 \cdot 0(0 \cdot 8)$ & $40 \cdot 5(2 \cdot 4)$ \\
\hline $\mathrm{BaSO}_{4}+\mathrm{Na}_{2} \mathrm{SO}_{4}$ & $1 \cdot 0$ & $0 \cdot 5$ & $5 \cdot 7 \mathrm{~g} \mathrm{SO}_{4}$ & $5 \cdot 3(0.3)$ & $32.7(0.7)$ & $6.9(0-3)$ & $38.0(0.4)$ \\
\hline $\mathrm{KH}_{2} \mathrm{PO}_{4}+\mathrm{CaCl}_{2}$ & $2 \cdot 5$ & $2 \cdot 4$ & $5.7 \mathrm{gPO}$ & $3 \cdot 3(0 \cdot 3)$ & $9 \cdot 9(0.8)$ & $4 \cdot 1(0.4)$ & $10 \cdot 3(0 \cdot 8)$ \\
\hline $\mathrm{Na}$ alginate 1 (I, D.II.)* & 1.0 & 0.5 & $10 \mathrm{~g}$ & $4 \cdot 2(0.2)$ & $27.0(1.1)$ & $5 \cdot \overline{0}(0 \cdot \overline{2})$ & $28.6(1.0)$ \\
\hline Na alginate 2 ('Manucol' $S S / L D / 2$ ) $\dagger$ & $1 \cdot 0$ & $0 \cdot 5$ & $10 \mathrm{~g}$ & $3 \cdot 0(0.2)$ & $27.3(0.9)$ & $3.7(0.2)$ & $28 \cdot 6(1 \cdot 0)$ \\
\hline Na alginate 2 & $1 \cdot 0$ & 0.5 & $20 \mathrm{~g}$ & $1 \cdot 7(\theta \cdot 1)$ & $22.3(0.9)$ & $2.0(0.2)$ & $24.1(0 \cdot 7)$ \\
\hline $\mathrm{Na}$ alginate 2 and $\mathrm{KH}_{2} \mathrm{PO}_{4}+\mathrm{CaCl}_{4}$ & $2 \cdot 5$ & $2 \cdot 4$ & $\begin{array}{c}10 \mathrm{~g}+5 \cdot 7 \mathrm{~g} \\
\mathrm{PO}_{4}\end{array}$ & $1 \cdot 5(0 \cdot 1)$ & $9 \cdot 0(0.5)$ & $2 \cdot 3(0.2)$ & $10 \cdot 4(0.5)$ \\
\hline
\end{tabular}

* British Drug Houges (batch No. 2492290).

+ Alginate Industrieg, Itd., London.

$\$$ Figures in parentheses are standard errors of the mean. 